\title{
Impact of External Auditing Quality and Audit Committees on Accounting Conservatism and the Performance of Industrial Firms Listed at the Amman Stock Exchange
}

\author{
Mahmod AL-Rawashdeh Abdalwahab ${ }^{1}$ \& Riham Fathi ALkabbji ${ }^{1}$ \\ ${ }^{1}$ Accounting Department, Faculty of Economics and Administration Sciences, Zarqa University, Jordan \\ Correspondence: Dr Riham Fathi ALkabbji, Accounting Department, Faculty of Economics and Administration \\ Sciences, Zarqa University, Zarqa 13110, Jordan. E-mail: riham.f.r.k@ hotmail.com
}

Received: March 16, 2020

Accepted: April 29, 2020

Online Published: July 15, 2020

doi:10.5430/ijfr.v11n4p556

URL: https://doi.org/10.5430/ijfr.v11n4p556

\begin{abstract}
This study aims to investigate the impact of external auditing quality and audit committees on accounting conservatism and the performance of industrial firms listed at the Amman Stock Exchange. The study has relied on the industrial sector which comprised of 70 industrial firms, while the sample size comprised 54 firms. Audit quality has been addressed in terms of audit quality features (communication with world audit offices, keep client period, audit fees, accounting specialist in the customer industry), while audit committees quality has been analyzed (audit committees independence, audit committees expertise, audit committees meetings). The accruals model has been used to measure accounting conservatism. The firm`s performance has been measured through its market value. The study concluded that audit committees have no impact on accounting conservatism and firm`s performance, while audit quality features have a positive impact on accounting conservatism and firm`s performance. The study has recommended the need to activate the role of audit committees in public shareholding industrial firms since they positively have an impact on raising audit efficiency and control the regulate the firm`s internal control system.
\end{abstract}

Keywords: audit committees, external auditing quality, accounting conservatism, financial reports

\section{Introduction}

This study investigates the impact of audit committees and external auditing quality on accounting conservatism, and the role of accounting conservatism in raising the market value of public shareholding industrial firms. Audit committees emerged as a result of the Sarbanes- Oxley Act of 2002, to insure the quality of financial information through regulating internal control systems, with the aim of protecting the current investors rights and providing potential investors with accurate information. Audit committees have also a role in ensuring the external auditor`s impartiality and independence, who, in turn, gives the personnel reasonable assurance on the integrity of financial statements. Therefore, audit committees and external auditing aim at reducing the gap of expectations that investors undergo continuously, providing more accurate data to financial statements users since the main item for financial statements users lies in the accounting net profit, and the variety of tools used in preparing such financial reports affect profits results. So firms strive to disclose on their profits transparently, while trying to raise the accounting conservatism level in preparing financial reports to enhance the credibility of such.

Assessing corporate performance helps to provide a great deal of transparency to new and old investors. Thus, the performance of the firm reflects positively on shares market value by increasing their proportion of profits. The greater the credibility and transparency, the higher the firm performance, where audit committees and external auditing quality are the main factors increasing this credibility and transparency, also affecting accounting conservatism which aim at raising transparency, and eventually affecting positively on the firm performance and value. Hence, the following question is formulated:

Do audit committees and external auditing quality have an impact on the firm`s performance in the light of accounting conservatism?

To answer the above question, this study has been applied to industrial firms listed in the Amman Stock Exchange, aiming to investigate the impact of audit committees and external auditing in the light of accounting conservatism on 
industrial firms value. The study shall assist listed industrial firms in assessing adopted accounting systems as well as evaluate the external auditing quality and audit committees efficiency.

\section{Literature Review}

Very few studies have addressed the impact of audit committees on the accounting conservatism or the firm 's market performance. These studies have measured audit committees as an element of corporate governance. In this regard, Al-Ebweni \& Al-Omari (2017) indicated that audit committees have a negative impact on the firm`s value. The study points out that this is due to the lack of experience from the part of audit committees as well as the inefficiency of the board of directors in corporate governance. Krishnan and Visvanathan (2007) discovered that experience of the Audit Committee, one of the pillars of corporate governance, affected the degree of accounting conservatism. Yaseen, (2008) did not find any influence of the corporate governance on the relation between accounting conservatism and the improvement of quality of disclosure To the knowledge of both researchers, there has not been any studies on the impact of audit committees on accounting conservatism, while some studies have addressed the impact of external audit quality on accounting conservatism, such as Hamdan (2012) which investigated the impact of audit quality features (size of audit office, communication with world audit offices, keep client period, audit fees, accounting specialty in the customer industry) on improving accounting conservatism, employing a number of audit committees members and the scientific specialty of audit committees members as control variables. The study concluded that some audit quality features (the size of the audit office and accounting specialty in the customer industry) have a positive impact on accounting conservatism while the other variables showed no impact. Dabbas (2017) also investigated the impact of audit quality features on the market share price of banks listed on the Amman Stock Exchange. The variables used to measure the audit quality were similar to those used in Hamdan`s, namely (the size of the audit office, audit fees, the specialty in audit operations). The study comprised 14 banks listed in the Amman Stock Exchange. It concluded that there is a positive impact of audit quality on the shares market price. Hamdan (2012) and Dabbas (2017) proved that external audit features have an impact on accounting conservatism and the shares market price.

On the other hand, the impact of accounting conservatism on profits quality has been addressed by Shaheed \& Obais (2017). The study concluded that there is a difference in accounting conservatism rates between firms and the different years for firms listed in Damascus Securities Exchange. The aim of this study resembles the current study, where profits are the main indicators of the rise and fall in the firm`s value. An-Najjar (2014) measured the accounting conservatism level in financial statements and reports and its impact on the shares market value. The results of the study indicated a fall in accounting conservatism level in the financial reports and statements issued by Palestinian public shareholding firms. The study recommended the need to activate the role of the authority supervising the financial market aiming at activating surveillance on financial disclosure, obliging firms to increase conservatism levels within reasonable levels, the need to express views from the part of external auditors on the conservatism level adequacy within published financial statements and reports. It is noted that Al-Najjar recommended the need to activate the supervisory role and the role of the external auditor in raising the accounting conservatism level due to their active role in increasing the effectiveness of accounting conservatism. The financial control is represented by the firm`s audit committees. Mashoka \& Abu-Hommos (2018), "The Effect of Conservatism on Earning Quality" confirmed what was concluded in Al-Najar`s.

Saif Khan, et.al (2019) in a study entitled "The Firms Audit Committee and External Auditor Influence Accounting Conservatism and Firm's Performance", Saif lined up all common points from previous studies. The study aimed at investigating the impact of internal audit committees and external auditing quality on accounting conservatism in Malaysian public shareholding firms. All public shareholding firms were selected, amounting to 543, from 2004-2013. The study also investigated the utilization of accounting conservatism on the firm `s market performance. The study addressed whether accounting conservatism played as a mediator for the relationship between audit committees and external auditing quality on the firm`s market performance. The study found that audit committees and external auditing quality have an effective impact on accounting conservatism on an accrual basis. Accounting conservatism is also considered a mediator in measuring the impact of audit committees on the firm's market performance, as well as in measuring the impact of external audit quality on the firm's market performance.

This study is similar to the current study, however, the difference lies in the different financial market and sector. The current study is based on financial data of all public shareholding industrial firms listed in Amman Stock Exchange. There is also a difference in time, where the current study relied on financial data from 2014-2018.

\section{Study Methodology}

Public shareholding firms shall abide by audit committees standards and external auditing standards, since this shall enhance the credibility and transparency of financial data. This conforms with the aim of accounting conservatism, 
which also enhances the credibility and transparency of financial data, thus increasing the firm`s performance. The study has been applied to industrial firms listed in Amman Stock Exchange, aiming at investigating the impact of audit committees and external audit in the light of accounting conservatism on the performance of industrial firms. Audit committees and external audit assist listed industrial firms in assessing adopted accounting systems as well as evaluate external auditing quality and audit committee efficiency.

\subsection{Study Sample and Population}

The study population comprised 70 industrial firms, whereas the study sample included 54 industrial firms. This number is appropriate as per Steven Thompson`s equation, (Steven, 2012). The financial data of the mentioned firms for the period between 2014 and 2018 have been used.

\subsection{Variables Measurement}

This study adopted in measuring the variables on the previous studies, measurement method will be displayed each variable.

\subsection{Study Hypotheses}

The following main hypothesis was formulated:

The impact of audit committees and the external auditing quality features on firms` market value and accounting conservatism.

The following hypotheses branch from the previous main hypothesis:

- H1: there is no positive impact of audit committees on the accounting conservatism degree

- H2: there is no positive impact of external auditing quality on accounting conservatism

- H3: there is no positive impact of accounting conservatism on the firm`s performance

- H4: There is no positive impact of audit committees on the firm`s performance

- H5: There is no positive impact of audit quality on the firm`s performance

- H6: There is no positive impact of audit committees and external auditing quality on the firm`s performance in light of accounting conservatism

\subsection{Study Variables}

\subsubsection{Measuring the Auditing Quality}

The audit quality reflects the efficiency of the audit process, its ability to obtain evidence to support the external auditor's opinion, the ability to require the firm's management to apply accounting principles, reduce fraud, manipulate financial statements, and Reduce earning management practices, The majority of previous studies have identified the following elements to measure the quality of external auditing: Auditor's independence, Auditor's brand name, Auditor's specialist in the customer's industry.

\section{Testing the Audit Quality Level of the Study Sample}

The audit quality was tested through External Auditor Quality (EAQ):

Auditor's independence (AI): The independence of the auditor was measured in terms of the auditor's fees ratio from tasks other than audit during the period, where

the value of the dummy variable was (1), where the auditor`s fees during the financial year from tasks rather than audit did not exceed $20 \%$ and (0) otherwise

Auditor's specialist (AS): Specialty in auditing: the auditor is a specialist in the customer's industry where the value of the dummy variable was (1) for the professional auditor and (0) otherwise.

Auditor's brand name $(\mathrm{ABN})$ : This variable was measured through the audit offices contracted with the firm, where it was given a dummy variable value of (1) in case it is a big 4, and (0) otherwise.

Auditor's Keep client (AKC): Keep client was measured through the continuity duration between the auditor and client. In case it exceeded three years, it was given a dummy variable value of (1) and (0) otherwise.

The following equation has been applied to the external auditing quality by using a five-year time series.

$$
\mathrm{EAQ}=\alpha+\beta 1 \mathrm{AI}+\beta 2 \mathrm{As}+\beta 3 \mathrm{ABN}+\beta 4 \mathrm{ABN}
$$


The following table shows the audit quality level in the industrial public shareholding firms listed at Amman Stock Exchange.

Table 1. Audit quality features

\begin{tabular}{|c|c|c|c|c|}
\hline & Category & $\mathrm{N}$ & Observed Prop. & $\begin{array}{l}\text { Exact Sig. } \\
\text { (tailed-2) }\end{array}$ \\
\hline \multirow{2}{*}{$\mathrm{AI}$} & non audit fee less $20 \%$ & 38 & 70. & \multirow{2}{*}{004} \\
\hline & otherwise & 16 & 30. & \\
\hline \multirow{2}{*}{$\mathrm{AS}$} & audit specialist & 54 & 1.00 & \multirow{2}{*}{000} \\
\hline & otherwise & 0 & 0 & \\
\hline \multirow{2}{*}{$\mathrm{ABN}$} & audit firm one big4 & 40 & 74. & \multirow{2}{*}{001} \\
\hline & otherwise & 14 & 26. & \\
\hline \multirow{2}{*}{$\mathrm{AKC}$} & keep client more than 3 year & 39 & 72. & \multirow{2}{*}{001} \\
\hline & otherwise & 15 & 28. & \\
\hline
\end{tabular}

This step precedes testing the study hypotheses, aiming at measuring the auditing quality in industrial public shareholding firms. The four auditing quality features were tested. The binomial test was used since these variables distribution follows the binomial distribution, being the mostly used for the binomial test. Results from the previous table indicate the auditing quality features in industrial public shareholding firms listed at Amman Stock Exchange have achieved a high ratio at achieved a high proportion at a level of significance of $5 \%$. Based on these results, audit offices that performed audit services at industrial public shareholding firms during the period 2013-2018 have audit quality features.

\subsubsection{Measuring the Internal Audit Committees}

The audit committees were measured based on the companies' management instructions listed for 2017 in Jordan that defined the characteristics of the audit committees in terms of independence, experience and number of times of meetings during the fiscal year. https://www.ase.com.jo/sites/default/files/2018-11/Corporate_Governance_Regulations.pdf

\section{Testing the Level of Effectiveness of Internal Audit Committees in the Study Sample}

The effectiveness of audit committees (ACE) has been measured by:

Audit Committee independence (ACI ): if stemmed from the board of directors, it takes the dummy variable value (1), otherwise, it takes the dummy variable value (0).

Audit committee expertise (ACE): if at least one member of the committee has financial professional expertise, it takes the dummy variable value (1), otherwise (0)

Audit committee diligence (ACD): if the committee meets more than five times a year, it takes the value (1), otherwise (0)

The following equation has been applied to measure the effectiveness of audit committees by using a five-year time series.

$$
\mathrm{ACE}=\alpha++\beta 1 \mathrm{ACI}++\beta 2 \mathrm{ACE}+\beta 3 \mathrm{ACD}
$$

The following table shows the effectiveness of internal audit committees level in the industrial public shareholding firms listed at Amman Stock Exchange. 
Table 2. Internal audit committees

\begin{tabular}{|c|c|c|c|c|}
\hline & Category & $\mathrm{N}$ & Observed Prop. & $\begin{array}{l}\text { Exact Sig. } \\
\text { (tailed-2) }\end{array}$ \\
\hline \multirow[t]{2}{*}{ ACI } & independent chairman & 52 & 96. & \multirow{2}{*}{000.} \\
\hline & non independent chairman & 2 & 04. & \\
\hline $\mathrm{ACE}$ & financial provincial & 54 & 1.00 & 000. \\
\hline \multirow[t]{2}{*}{$\mathrm{ACD}$} & meeting or more 5 & 31 & 57. & \multirow{2}{*}{341.} \\
\hline & less than 5 meeting & 23 & 43. & \\
\hline
\end{tabular}

In the same way, the binomial test was used to measure the effectiveness of the audit committees in the study sample. Test results showed that audit committees enjoyed high independence in industrial firms, where $96 \%$ of which came directly from the board of directors. This is a high ratio at the level of significance 5\%. Similarly, the specialist level of the internal audit committee members achieved a top grade at the level of significance 5\%, whereas audit committees meetings to discuss issues were not sufficient achieving an insignificant result at the level 5\%. This weakens the efficiency of audit committees, which play a protective role in the control system and risks management, while ensuring the importance of directing attention to control mechanisms and policies that prevent financial and operational disasters.

\subsubsection{Measuring the Accounting Conservatism Application Level}

Accounting conservatism: accounting conservatism was measured as per the accruals model Ball and Shivakumar, 2005; Duellman, 2006

\section{Testing the accounting conservatism application level as per the accruals entry model}

Accruals model: cash flows of operational activities / net profit

Accruals entry model: operating cash flow divided by net profit. If the accruals value is negative during the time period, this is due to fact that the cash flow are constant compared to the profits. This means that the firm has been practicing conservative accounting policies that lead to the reduction of the profits declared by the firm (Al-Najjar, 2014). The accruals model was applied as per the following equation:

\section{$\mathrm{OCF} \alpha \pm \beta 1 \beta / 2 \mathrm{EBIT}=\mathrm{ACCRCON}$}

ACCRCON: accounting conservatism as per the accruals model

OCF: cash flows from operational activities.

EBIT: net profit before interest and taxes

Table 3. The results of the application of the accruals model

\begin{tabular}{lll}
\hline Accruals model positive & Accruals model negative & Number of companies in the study sample \\
\hline 6 & 48 & 54 \\
\hline 0.111111 & 0.888889 & \\
\hline
\end{tabular}

The previous table shows that the ratio of firms that enjoy a high level of application of accounting conservatism as per the accruals model is a high one compared to other firms.

\subsubsection{Measuring the Firm Performance}

The firm`s performance was measured using Tobin's ratio.

Firm`s market performance MPER $=$ market value of ordinary shares + book value of liabilities / book value of assets.

\subsection{Testing Hypotheses and Analyzing Results}

Analysis of hypotheses:

The regression formula was applied to test the study hypotheses at a significance level $10 \%$. The following table shows the test results. 
Table 4. Testing hypotheses

\begin{tabular}{|c|c|c|c|c|}
\hline Hypothesis & Model & $\beta$ & $\mathrm{p}$ & Result \\
\hline H1 & $\mathrm{ACE}=\alpha \pm \beta 1$ Accrual & 0.028 & 0.12 & NO \\
\hline $\mathrm{H} 2$ & $\mathrm{EAQ}=\alpha \pm \beta 1$ Accrual & 0.15 & $0.095^{*}$ & YES \\
\hline $\mathrm{H} 3$ & $\mathrm{MBFP}=\alpha \pm \beta 1$ Accrual & 0.18 & 0.046 & YES \\
\hline $\mathrm{H} 4$ & $\mathrm{MBFP}=\alpha \pm \beta 1 \mathrm{ACE}$ & $1.236-$ & 0.222 & NO \\
\hline H5 & $\mathrm{MBFP}=\alpha \pm \beta 1 \mathrm{EAQ}$ & 0.34 & .0 .08 & YES \\
\hline H6 & $\mathrm{MBFP}=\alpha \pm \quad \beta 1 \mathrm{EAQ} \pm \quad \beta 2$ Accrual & $\begin{array}{l}\beta 1=0.2 \\
\beta 2=-0.15\end{array}$ & 0.075 & YES \\
\hline
\end{tabular}

It is noted from the table 4 that the null hypothesis has been accepted for the first and fourth hypotheses relating to the impact of audit committees on accounting conservatism $\mathrm{H} 1$ and on the firm`s market performance $\mathrm{H} 4$ at the level of significance $10 \%$ where these results indicated that the presence of audit committees have no impact on accounting conservatism and the firm`s market performance. This conforms with Al-Ebweni\& Omari (2017) in terms of the impact of audit committees on the firm`s market performance. The null hypothesis relating to external auditing quality has been rejected, while the alternative hypothesis has been accepted, where audit quality has an impact on accounting conservatism $\mathrm{H} 2$ and the firm`s market performance $\mathrm{H} 5$, that there is positive impact of quality audit on both accounting conservatism and the market performance of the firm. This emphasizes the need to drive attention to external audit quality in public shareholding firms. This conforms with Hamda (2012) and Dabbas (2017. The null hypothesis $\mathrm{H} 3$ regarding the impact of accounting conservatism on the company's market performance has been rejected, and the alternative hypothesis has been accepted at level of significance 5\%. The study showed that accounting conservatism has a positive impact on the firm`s market performance separately or jointly with audit quality features. These results contradict what was concluded by Al-Najjar (2014). The alternative hypothesis H6 stating that both accounting conservatism and audit quality have an impact on the firm`s market performance has been accepted at the level of significance $10 \%$. The variable related to audit committees has been removed from the model due to the nonexistence of positive impact in the sub-hypotheses ( $\mathrm{H} 1, \mathrm{H} 4)$.

\section{Discussion of Results}

It is noted from the previous analysis that the firms have a high level of audit quality features. This is consistent with the analysis of the hypotheses where the results of the analysis of hypotheses (H2) and (H5) that there is positive impact of quality audit on both accounting conservatism and the market performance of the firm. This emphasizes the need to drive attention to external audit quality in public shareholding firms. This conforms with Hamda (2012) and Dabbas (2017). Whereas the analysis results of the effectiveness of audit committees indicate that effectiveness is found in the independence and financial expertise of the committee members, while the effectiveness and efficiency of the audit committee is rather weak, since meetings of committees in most firms is less than 5 times a year. This corresponds to the analysis results of the hypotheses (H1) and (H4), where these results indicated that the presence of audit committees have no impact on accounting conservatism and the firm`s market performance. This conforms with Al-Ebweni\& Omari (2017) in terms of the impact of audit committees on the firm's market performance. The presence of audit committees having no impact on accounting conservatism is rather considered a new result attributed to this study. On the other hand, the study contradicts Saif khan (2019), which confirmed that the presence of audit committees have a positive impact on accounting conservatism. This contradiction is attributed to the difference in the study environment as mentioned earlier, while the overall weakness in audit committees impact indicates weakness in corporate governance in Jordanian industrial public shareholding firms, since audit committees stem from the board of governance.

Results of the accounting conservatism application level test as per the accruals entry model indicated that the accounting conservatism as per the accruals entry is applied with high efficiency in Jordanian industrial firms. Hypotheses (H3, H6) confirm these results. The study showed that accounting conservatism has a positive impact on the firm`s market performance separately or jointly with audit quality features. These results contradict what was concluded by Al-Najjar (2014) that there is a decrease in accounting conservatism level in financial data of public shareholding firms at Palestine Stock Exchange. The logical explanation for such a contradiction lies in the difference in the study environment, difference in the study time period and the difference in the political and economic conditions of both countries. Whereas, this conforms with what was concluded by Saif khan (2019) The 
current study concludes that the firm`s external auditing quality have a positive impact in the light of accounting conservatism as per accruals.

\section{Recommendations}

Based on the results concluded by the study, the researchers have proposed a number of recommendations, namely:

After testing the hypotheses and discussing the results, the researchers recommend the following:

1). The need to activate the role of audit committees, since audit committees members are responsible for the effectiveness and efficiency of internal control systems applied in the firm and risk management. Audit committees are the main supervisory committee stemming from the board of directors or from the shareholders general assembly.

2). The need to increase the number of audit committees meetings, increase the length of time for each meeting, prepare in advance for these meetings, document resolutions and recommendations as well as the discussion of important issues, report periodically on the work of the committee to the board of directors or the shareholders general assembly.

3). Increasing the number of studies on audit committees due to their importance in the tuning of internal control systems, convergence of views between the internal and the external auditor, as well as preserving firms`internal systems.

\section{References}

Al-Najjar, J. H. (2014). Measuring the level of transformation of accounting in financial statements and reports and its impact on the market value of the shares applied study on public shareholding companies listed in the Palestine Exchange. Al-Balqa`Journal, 17(2), 177-224.

Ball, R., \& Shivakumar, L. (2005). The role of accruals in asymmetrically timely gain and loss recognition. Journal of Accounting Research.

Corporate Governance Regulation for 2017. Retrieved from https://www.ase.com.jo/sites/default/files/2018-11/Corporate_Governance_Regulations.pdf

Dabbas Qasim Ahmed. (2017). The impact of audit quality on the market value of the shares in the banks of Jordan. The first international scientific conference: control and anagement of risk in Islamic financial industry, pp. 265-292.

Hamdan, A. M. (2012). The impact of the characteristics of audit quality in improving the level of transformation of accounting in corporate public shareholding industrial Jordanian. Periodic of Public Administration, 52(4), 589-613.

Khan, S., Khan, H., \& Khan, F. (2019, January). Firms Audit Committee and External Auditor Influence Accounting Conservatism and firm's Performance. International Journal of Management, Accounting and Economics, 6(1).

Krishnan, J., \& Visvanathan, G. (2007). Does the SOX definition of an accounting expert matter? The association between audit committee directors' accounting expertise and accounting conservatism. Contemporary Accounting Research, 25(3), 827-857.

Mashoka,T., \& Abu-hommous, A. (2018). The Effect of Conservatism on Earning Quality. Jordan journal of business Administration, 14(1), 165-174.

Matar, M., \& Suwati, M. (2012). Theoretical origin of professional and accounting practices (3rd ed.), p. 121. Wael Publishing House.

Obweini, M. H., \& Omari, A. M. (2016). The impact of corporate governance and the leverage of the maladies of the value of industrial companies listed in Amman Stock Exchange. The Jordanian Journal in Business Administration, 12(4), 899-914.

Shahid, R., \& Abbs, F. M. (2017). Measuring accounting restraint and showing its impact on the quality of accounting profits), applied study on the Damascus Stock Exchange. Al-Quds Open University Journal, 2(42), $133-142$.

Steven, K. T. (2012). Sampling (3rd ed.), pp. 59-60.

Yaseen, M. (2008). Measure the level of conservatism in accounting light of corporate governance and its impact on the disclosure quality of the financial statements of the Jordanian commercial banks. Arab Academy for Banking and Financial Sciences (Unpublished dissertation). 